\title{
Quality of Briquettes Produced with Jatropha and Eucalyptus
}

\author{
Cynthia Patricia de Sousa Santos ${ }^{1}$ (1) 0000-0002-3657-5565 \\ Rosimeire Cavalcante dos Santos ${ }^{1}$ (D) 0000-0002-4234-3998 \\ Angélica de Cássia Oliveira Carneiro² (1) 0000-0002-5992-3059 \\ Ana Flávia Neves Mendes Castro ${ }^{3}$ (1) 0000-0001-7707-1569 \\ Renato Vinícius Oliveira Castro ${ }^{3}$ (1) 0000-0001-9018-7793 \\ Sarah Esther de Lima Costa ${ }^{1}$ (1) 0000-0002-4320-8907 \\ Izabelle Rodrigues Ferreira Gomes ${ }^{1}$ (D) 0000-0001-9469-6990 \\ Krisnara Soares Mairinck ${ }^{3}$ (1) 0000-0003-4997-9910
}

\begin{abstract}
Our study aims to determine the energetic quality of residues from the manufacturing of jatropha and eucalyptus, as well as to evaluate the physical properties of the briquettes made with different proportions of these biomasses. The following proportions were used for this study: $100 \%$ eucalyptus; $75 \%$ eucalyptus; $50 \%$ jatropha and $50 \%$ eucalyptus; 75\% jatropha; and $100 \%$ jatropha. The apparent density of the residues, the immediate chemical product, the highest calorific value (HCV), the apparent density, the energy density, the usable calorific value (UCV), the lowest calorific value (LCV), the breaking strength of the briquettes (FR) and the hydroscopic moisture balance (HMB) were verified. Although the energetic characteristics of the jatropha residues are not superior to those of eucalyptus, this biomass adds favorable mechanical characteristics to the briquettes comprised of greater proportions of jatropha to eucalyptus, guaranteeing the energetic properties of the briquette, as well as reducing the production cost.
\end{abstract}

Keywords: combustible solid, biomass energy, manufacturing briquettes.

\section{INTRODUCTION AND OBJECTIVES}

For some decades, most countries have found alternative energy sources that are economically competitive, environmentally acceptable and available on a large scale (Srivastava \& Prasad, 2000). One of these sources is jatropha (Jatropha curcas L.), which presents advantages in the production such as quality oil, long productive period, resistance to pests and disease, as well as adaptability to diverse edaphoclimatic conditions recurrent in Brazil (Arruda et al., 2004; Oliveira et al., 2009; Teixeira, 2005).

Jatropha curcas L., more than other oleaginous species, has already been established in the field of energy sources, presenting a satisfactory seed production when irrigated (about 2,500 kg.ha- ${ }^{-1}$ within the fourth year after planting) and yielding between 30 to $40 \%$ oil, which can later be transformed into biodiesel (Achten et al., 2007; Drummond et al., 1984; Saturnino et al., 2005). Recent numbers indicate there is approximately 20,000 ha of plantations of jatropha in Brazil, distributed throughout different states, spreading gradually as studies on the management and improvement of the agronomy are developed (Durães et al., 2009).

Although jatropha encourages the intense manufacturing of biodiesel by being a solid competitor to its petroleum alternative, this activity produces great amount of residues, since the seeds total 53 to $79 \%$ of the fruit weight, and the remainders are discarded after oil extraction (Dias et al., 2007). Thus, the fruit is more valued in terms of energy production, between 17 and $18 \%$ of the dry fruit, and the use of diverse residues and constituents is reduced (Singh et al., 2008).

While agricultural activities generate residues after extraction of the desired product (the cultivation of jatropha

\footnotetext{
${ }^{1}$ Universidade Federal do Rio Grande do Norte (UFRN), Natal, RN, Brasil

${ }^{2}$ Universidade Federal de Viçosa (UFV), Viçosa, MG, Brasil

${ }^{3}$ Universidade Federal de São João del-Rei (UFSJ), Sete Lagoas, MG, Brasil
} 
included), forestry activities such as the lumbering of eucalyptus wood notably generate passive residues that can be used as potential energy sources. During the eucalyptus wood harvest, the economically viable part (for the manufacture of paper, cellulose, charcoal, wood plank, the mechanical transformation of the trunks in planks, as well as wood artifacts and treated wood industries) is taken, leaving the remains, ends and branches to be potentially used as biomass and energy sources (Ricardo, 2014).

For Dias et al. (2012) the agroforestry sector (the biggest industry in Brazil) generates a significant amount of residues that can be transformed in pellets and briquettes. Several studies have examined the manufacturing and the quality of briquettes, in their total composition, as potential energy sources of biomass, obtained from agriculture or forestry, such as the one carried out by Tomeleri et al. (2017) which identified the potential of the briquettes produced with jatropha to create energy; as well as Silva et al. (2015), who characterized briquettes produced with eucalyptus shavings. However, very few scientific studies on the manufacturing of these combustible solids consider different proportions of agroforestry sources or the advantages of the physical characteristics of the briquettes when using two biomass potential energy sources in the same combustible solid. Given this, the objective of this study is to investigate the quality of the energy of jatropha and eucalyptus residues, and the implication of the physical properties in the manufacturing of briquettes composed of different proportions of biomasses.

\section{MATERIALS AND METHODS}

\subsection{Preparation and characterization of the materials}

For this study, jatropha epicarp obtained from the manufacturing of biodiesel as well as leaves and tips of eucalyptus (with a maximum diameter of $3 \mathrm{~cm}$ ) were used, with both residues originating from the region of Viçosa, Minas Gerais. In order to carry out the granulometry needed for the energy quality analysis, the biomass was ground in a hammer mill with a screen of $2 \mathrm{~mm}$ following the Tappi $257 \mathrm{om}-52$ (TAPPI, 1998) recommendations. The verification of the moisture of the material was carried out by a thermogravimetric scale (MB35 Halogen, Ohaus brand model). After trituration, the particles were classified in sifters with the 40 and 60 mesh screens, used in proportion to the final sifter.

Apparent density was measured using an analytic scale and beaker $\left(0.001 \mathrm{~m}^{3}\right)$, filling the glass container with the jatropha epicarp and the eucalyptus biomass to the top, adapted to the standard EN 15103: DIN (CEN, 2009). Based on the knowledge of the volume and mass of the recipient, as well as the biomass contained in it, the apparent density was determined (1):

$$
\text { Bulk density }\left(\mathrm{kg} / \mathrm{m}^{3}\right)=\frac{\text { Mass of the biomass }(\mathrm{kg})}{\text { Beaker volume }\left(\mathrm{m}^{3}\right)}
$$

The biomass was characterized by its immediate chemical composition, its volatility level, ash content and fixed carbon according to the ABNT NBR 8112 (ABNT, 1986), while the highest calorific value was determined according to the ABNT NBR 8633 (ABNT, 1984).

\subsection{Briquette production}

A total of 25 briquettes were produced with $18 \mathrm{~g}$ of biomass each, pre-determined temperature and pressure $\left(120^{\circ} \mathrm{C}\right.$ and $1500 \mathrm{psi}$ ), during 5 minutes of compression and 5 minutes of cooling in the Lippel (LB-32) laboratorial briquetting model, according to procedures described in Freitas et al. (2016). The biomasses studied were briquetted at a moisture level of 7.7\% for the jatropha epicarp and $8.2 \%$ for the eucalyptus residue.

\subsubsection{Characterization of the briquettes}

Using an analytic scale and a beaker of volume $1,000 \mathrm{~m}^{3}$ filled with mercury, the apparent density was determined by immerging the briquettes in the container according to the principle of the hydrostatic scale described by Vital (1984). In addition, the energy density $\left(\mathrm{MJ} / \mathrm{m}^{3}\right)$ was defined according to the sum of the HCV by the apparent density of the briquettes. The HCV (3), was defined by the lowest calorific value (LCV) (2):

$$
\begin{aligned}
& \text { LCV }(\mathrm{kcal} / \mathrm{kg})=\text { Higher Heating Value }-(\mathrm{kcal} / \mathrm{kg})-324 \\
& \mathrm{HCV}(\mathrm{kcal} / \mathrm{kg})=[L C V \times(1-H)]-600 \mathrm{U} \\
& \mathrm{H}=\text { humidity in dry base (\%) }
\end{aligned}
$$

The breaking strength was determined by the Losenhausen universal testing machine using the software Pavitest wood 2.7.0.7. Given that there is no specific standard to evaluate the resistance to breakage of the briquettes, a methodology adapted from the ABNT NBR ISO 11093-9 (ABNT, 2009) standard was followed. In addition, the briquettes were inserted into a climatic chamber at $23{ }^{\circ} \mathrm{C}$ with $65 \%$ relative humidity until achieving constant weight, to determine the Hygroscopic Moisture Balance (HMB). 


\subsection{Data analysis}

The experiment strictly followed a causal outline, with three repetitions for the analysis of the biomass and five treatments and repetitions (Table 1) for the analysis of the briquettes. Measurements on the energy density, the highest calorific value and the lowest calorific value were carried out only for the $100 \mathrm{E}$ and $100 \mathrm{~J}$ treatments in order to characterize the biomasses, since the energy density is a variable dependent on the apparent density and $\mathrm{HCV}$, and these characteristics are intrinsic to each residue. Similarly, the LCV depends on the HHV and the HCV depends on the LCV, which are variables intrinsic to each residue.

Table 1. Experimental design adopted in the study.

\begin{tabular}{cl} 
Treatment & \multicolumn{1}{c}{ Composition } \\
\hline $100 \mathrm{E}$ & $100 \%$ eucalyptus \\
\hline $25 \mathrm{P} 75 \mathrm{E}$ & $25 \%$ jatropha $+75 \%$ eucalyptus \\
$50 \mathrm{~J} 50$ & $50 \%$ jatropha $+50 \%$ eucalyptus \\
$75 \mathrm{~J} 25 \mathrm{E}$ & $75 \%$ jatropha $+25 \%$ eucalyptus \\
$100 \mathrm{~J}$ & $100 \%$ jatropha \\
\hline
\end{tabular}

The Lilliefors test was used to verify the normality of the data and the homogeneity of the variances by Cochran. From this, the variance analysis was carried out using the F-test, with comparison of means by Tukey, at a 5\% significance level. The statistical software used was Statistica 8.0 (StatSoft, 2009).

\section{RESULTS AND DISCUSSION}

According to the analysis that qualifies the biomasses as energy sources, the residue of the eucalyptus showed characteristics that were superior in energy production than the jatropha residue (Table 2).

Among these characteristics, the apparent density of the eucalyptus residue is greater, making this biomass more workable as to the logistics, transportation and storing of these residues; given the data of the empty space in the biomass, the real volume can be determined (Garcia et al., 2013).

In general terms, the apparent density is related to the cost of transporting the residues to the site where they will be transformed into a combustible solid. In other words, the transportation of eucalyptus residue involves more mass per volume, greater calorific value and more energy per load when compared to the jatropha residue, which decreases the number of times this material need to be moved. Thus, an alternative to the use of the jatropha residue is its compression, whether through the briquetting or pelletizing process, in order to increase the energy density of the material.

Table 2. Mean values of the apparent density $\left(\mathrm{kg} / \mathrm{m}^{3}\right)$, fixed carbon (\%), volatile matter (\%), ash content (\%), and highest calorific value $(\mathrm{kcal} / \mathrm{kg})$ of eucalyptus and jatropha residues.

\begin{tabular}{lcc}
\multirow{2}{*}{\multicolumn{1}{c}{ Properties }} & \multicolumn{2}{c}{ Residues } \\
\cline { 2 - 3 } & Eucalyptus & Jatropha \\
\hline Apparent density $\left(\mathrm{kg} / \mathrm{m}^{3}\right)$ & $223.4 \pm 2.29 \mathrm{a}$ & $159.7 \pm 1.65 \mathrm{~b}$ \\
\hline Volatile matter $(\%)$ & $82.7 \pm 1.3 \mathrm{a}$ & $72.1 \pm 3.7 \mathrm{~b}$ \\
\hline Ash content $(\%)$ & $1.7 \pm 0.1 \mathrm{~b}$ & $12.9 \pm 0.4 \mathrm{a}$ \\
Fixed carbon $(\%)$ & $15.5 \pm 1.3 \mathrm{a}$ & $15.0 \pm 3.4 \mathrm{a}$ \\
\hline $\begin{array}{l}\text { Highest calorific } \\
\text { value (kcal/kg) }\end{array}$ & $4,992.5 \pm 41.72 \mathrm{a}$ & $4,034 \pm 24.04 \mathrm{~b}$ \\
\hline
\end{tabular}

No significant difference was found between the same letters among the residues (columns), for the same variable, using the Tukey $(p=0.05)$ test.

During the combustion process, the organic constituents of the biomass are consumed, and the resulting fraction of this component, as well as the oxidation of the inorganic composts, is known as ash content (Nogueira \& Rendeiro, 2008). According to Carvalho (2010), a potential energy source must have an ash content lower than $3 \%$, as the calorific value of the biomass is reduced and, consequently, the energy production for the reaction.

Consequently, by obtaining a lower ash content, the eucalyptus presents superior energetic characteristics when compared to the jatropha and thus the frequent cleaning of the equipment in the combustion process is recommended when using the latter for energy generation. Oliveira et al. (2007) explain the high ash content for the jatropha biomass by analyzing the epicarp and the residual press-cake of the jatropha, besides verifying high levels of ash content in the jatropha residue (15.9\% and $7.4 \%$ in the press-cake and in the epicarp, respectively), justified by the presence of high concentrations of inorganic composts. This behavior is generally observed in the biomass originating from agricultural species that require frequent fertilization with micronutrients as opposed to forest species.

Therefore, the ash content obtained in each biomass influenced the result of the highest calorific value, in which the eucalyptus residue presented greater advantage. Rodrigues (2010) confirmed the elementary chemical composition and the ash content are the main characteristics that interfere in the calorific value. The physical properties of briquettes produced with residues also influence the energy yield of the product, as shown in Table 3. 
Table 3. Mean values of the diameters ( $\mathrm{mm})$, lengths $(\mathrm{mm})$, highest calorific value ( $\mathrm{kcal} / \mathrm{kg})$, the lowest calorific value (kcal/kg), energy density $\left(\mathrm{MJ} / \mathrm{m}^{3}\right)$, breaking strength (Kgf), and hygroscopic moisture balance (\%) of the briquettes produced for each treatment.

\begin{tabular}{|c|c|c|c|c|c|}
\hline \multirow{2}{*}{ Properties } & \multicolumn{5}{|c|}{ Treatments } \\
\hline & $100 \mathrm{E}$ & 25P75E & 50P50E & 75P25E & $100 \mathrm{~J}$ \\
\hline Apparent density $\left(\mathrm{g} \cdot \mathrm{cm}^{-3}\right)$ & $1.07 \pm 0.02 \mathrm{e}$ & $1.12 \pm 0.01 \mathrm{~d}$ & $1.17 \pm 0.01 \mathrm{c}$ & $1.23 \pm 0.01 \mathrm{~b}$ & $1.28 \pm 0.01 \mathrm{a}$ \\
\hline $\begin{array}{l}\text { Lowest calorific value } \\
(\mathrm{kcal} / \mathrm{kg})\end{array}$ & $4,668.5 \pm 41.7 \mathrm{a}$ & - & - & - & $3,710 \pm 24.0 \mathrm{~b}$ \\
\hline $\begin{array}{l}\text { Usable calorific value } \\
(\mathrm{kcal} / \mathrm{kg})\end{array}$ & $4,285.9 \pm 38.6 \mathrm{a}$ & - & - & - & $3,382.6 \pm 22.2 \mathrm{~b}$ \\
\hline Energy density $\left(\mathrm{MJ} / \mathrm{m}^{3}\right)$ & $29.2 \pm 0 \mathrm{a}$ & - & - & - & $18.2 \pm 0 \mathrm{~b}$ \\
\hline Breaking strength (Kgf) & $168.2 \pm 13.55 c$ & $176.2 \pm 16.35 \mathrm{bc}$ & $182.2 \pm 9.15 b c$ & $216.4 \pm 9.96 \mathrm{a}$ & $200.2 \pm 25.07 \mathrm{ab}$ \\
\hline $\begin{array}{l}\text { Hygroscopic moisture } \\
\text { balance }(\%)\end{array}$ & $8,74 \pm 0,6 c$ & $9,19 \pm 0,04 \mathrm{c}$ & $9,67 \pm 0,06 \mathrm{bc}$ & $10,40 \pm 0,5 \mathrm{ab}$ & $10,79 \pm 0,09 \mathrm{a}$ \\
\hline
\end{tabular}

No significant difference was found between the same letters among the residues (columns), for the same variable, using the Tukey $(p=0.05)$ test.

The lowest calorific value and the usable calorific value differed significantly among the treatments analyzed $(100 \mathrm{E}$ and 100J), with the former presenting greater calorific value. This behavior is caused by the highest calorific value of the eucalyptus biomass and its apparent density. Thus, the 100J treatment obtained a lower energy density that, according to Vale et al. (2011), can be explained by the low calorific value and low apparent density of the jatropha epicarp.

However, as the concentrations of the jatropha residues are increased in the composition of the briquettes, the apparent density also increases and consequently provides greater resistance in the breaking strength (75J25E and 100J). According to Manriquez Figueiroa \& Moraes (2009), after the briquetting, the lignin contained in the biomass goes through a process known as glass transition, which promotes rigidity after being exposed to temperature and pressure, giving the briquette greater resistance.

The hygroscopicity is a tendency that some materials have of absorbing water in the air, raising the moisture of the composition. According to Yamaji et al. (2013), the biomass with the greater hygroscopicity tends to absorb more moisture and therefore reduces its physicomechanical properties. As the quantity of jatropha residue is increased in the composition of the briquettes, the hygroscopic moisture balance also increases. Thus, the briquettes with the highest jatropha compositions (75J25E and 100J) present a greater capacity to absorb moisture, when compared to briquettes with large proportions of eucalyptus (100E and 25J75E). Therefore, the storing of the briquettes made with percentages of jatropha should be done in a controlled environment, to maintain the physicomechanical qualities of the briquettes produced.

\section{CONCLUSIONS}

By presenting greater concentrations of inorganic materials, the residue of jatropha has a high ash content, which influences its highest calorific value. However, the addition of this residue in concentrations of the briquette provides a gain in apparent density and increases the resistance of its breaking strength when stored in an environment with humidity control. Hence, the association of the jatropha residue in greater concentrations than the eucalyptus (according to the description of the treatments 50J50E and 75J25E) adds mechanical resistance to the briquettes. Besides providing favorable mechanical characteristics, this composition can also reduce production costs in the process of manufacturing eucalyptus briquettes.

\section{SUBMISSION STATUS}

Received: 4 Oct. 2017

Accepted: 13 Sept. 2018

Associate editor: Edy Eime Baraúna

(D) 0000-0001-5239-9592

\section{CORRESPONDENCE TO}

\section{Renato Vinícius Oliveira Castro}

Universidade Federal de São João del-Rei (UFSJ), Departamento de Ciências Agrárias, Campus Sete Lagoas, Rua Setimo Moreira Martins, 188, CEP 35702-031, Sete Lagoas, MG, Brasil

E-mail: renatocastro@ufsj.edu.br

\section{REFERENCES}

Achten WML, Mathijs E, Verchot L, Singh VP, Aerts R, Muys B. Jatropha biodiesel fueling sustainability? Biofuels, Bioproducts \& Biorefining 2007; 1(4): 283-291. 10.1002/bbb.39 
Arruda FP, Beltrão NEM, Andrade AP, Pereira WE, Severino LS. Cultivo de pinhão-manso (Jatropha curcas L.) como alternativa para o Semiárido nordestino. Revista Brasileira de Oleaginosas e Fibrosas 2004; 8(1): 789-799.

Associação Brasileira de Normas Técnicas - ABNT. ABNT NBR 8633: carvão vegetal: determinação do poder calorífico: método de ensaio. Rio de Janeiro; 1984.

Associação Brasileira de Normas Técnicas - ABNT. ABNT NBR 8112: análise química imediata do carvão vegetal. Rio de Janeiro; 1986.

Associação Brasileira de Normas Técnicas - ABNT. ABNT NBR ISO 11093-9: papel e cartão: ensaio de tubetes. Rio de Janeiro; 2009.

Carvalho JBR. Composto a partir de glicerina e biomassa para produção de energia [thesis]. Aracaju: Universidade Federal de Sergipe; 2010.

Dias JMCS, Souza DT, Braga M, Onoyama MM, Miranda CHB, Barbosa PFD, Rocha JD. Produção de briquetes e péletes a partir de resíduos agrícolas, agroindustriais e florestais [Internet]. 2012 [cited 2020 Mar. 27]. Available from: https://bit.ly/2UnDCUI

Dias LAS, Leme LP, Laviola BG, Pallini Filho A, Pereira OL, Dias DCFS, et al. Cultivo de pinhão-manso (Jatropha curcas L.) para produção de óleo combustível. Viçosa: L. A. S. Dias; 2007.

Drummond OA, Purcino AAC, Cunha LHS, Veloso JM. Cultura do pinhão-manso. Belo Horizonte: Epamig; 1984.

Durães FOM, Laviola BG, Sundfeld E, Medonça S, Bhering LL. Pesquisa, desenvolvimento e inovação em pinhão-manso para produção de biocombustíveis. Brasília, DF: Embrapa; 2009. (Documentos; n. 1).

Comité Européen de Normalisation - CEN. EN 15103: Solid biofuels - Determination of bulk density. DIN EN 15103. Brussels; 2009.

Freitas AJ, Costa ACS, Oliveira AC, Pereira BLC, Rocha MFV, Carneiro ACO. Efeito da pressão e do tempo de compactação nas propriedades de briquetes de resíduos madeireiros de paricá. Nativa 2016; 4(6): 380-385. 10.14583/2318-7670.v04n06a06

Garcia DP, Caraschi JC, Ventorim G. Caracterização energética de pellets de madeira. Revista da Madeira 2013; 24(135): 14-18.

Manriquez Figueiroa MJ, Moraes PD. Comportamento da madeira a temperaturas elevadas. Ambiente Construído 2009; 9(4): 157-174.

Nogueira MFM, Rendeiro G. Caracterização energética da biomassa vegetal. In: Barreto EJF, coordenador. Combustão e gaseificação da biomassa sólida: soluções energéticas para a Amazônia. Brasília, DF: Ministério de Minas e Energia; 2008. p. 52-63.

Oliveira JB Jr, Marcela DN, Fraga AC, Castro Neto P. Determinação dos nutrientes presentes na casca e torta de pinhão-manso. In: $4^{\circ}$ Congresso Brasileiro de Plantas Oleaginosas, Óleos, Gorduras e Biodiesel; 2007; Varginha. p. 1763-1770.
Oliveira JS, Leite PM, Souza LB, Mello VM, Silva EC, Rubim JC, et al. Characteristics and composition of Jatropha gossypiifolia and Jatropha curcas $\mathrm{L}$. oil and application for biodiesel production. Biomass and Bioenergy 2009; 33(3): 449-453. 10.1016/j.biombioe.2008.08.006

Ricardo BH. Análise das atividades florestais desenvolvidas em uma empresa produtora de Eucalyptus spp. no estado do Mato Grosso do Sul [undergraduate thesis]. Curitibanos: Universidade Federal de Santa Catarina; 2014.

Rodrigues VAJ. Valorização energética de lodo biológico da indústria de polpa celulósica através da briquetagem [thesis]. Viçosa: Universidade Federal de Viçosa; 2010.

Saturnino HM, Pacheco DD, Kakida J, Tominaga N, Gonçalves NP. Cultura do pinhão-manso (Jatropha curcas L.). Informe agropecuário 2005; 26(229): 44-78.

Silva DA, Nakashima GT, Barros JL, Da Roz AL, Yamaji FM. Caracterização de biomassas para a briquetagem. Floresta 2015; 45(4): 713-722. 10.5380/rf.v45i4.39700

Singh RN, Vyas DK, Srivastava NSL, Narra M. SPRERI experience on holistic approach to utilize all parts of Jatropha curcas fruit for energy. Renewable Energy 2008; 33(8): 1868-1873. 10.1016/j. renene.2007.10.007

Srivastava A, Prasad R. Triglycerides-based diesel fuels. Renewable and Sustainable Energy Reviews 2000; 4(2): 111-133. 10.1016/S13640321(99)00013-1

StatSoft. Statistica: data analysis software system, version 8. Berlin; 2009.

Technical Association of the Pulp \& Paper Industry - TAPPI. TAPPI test methods. Atlanta; 1998.

Teixeira LC. Potencialidades de oleaginosas para produção de biodiesel. Informe Agropecuário 2005; 26(229): 18-27.

Tomeleri JOP, Valentim LB, Silva JP, Yamaji FM, Pádua FA. Caracterização química e energética de epicarpo residual do pinhão manso (Jatropha curcas L.) e briquete produzido. Revista Virtual de Química 2017; 9(3): 942-952. 10.21577/1984-6835.20170061

Vale AT, Mendes RM, Amorim MRS, Dantas VFS. Potencial energético da biomassa e carvão vegetal do epicarpo do pinhão manso (Jatropha curcas). Cerne 2011; 17(2): 267-273. 10.1590/ S0104-77602011000200015

Vital BR. Métodos de determinação da densidade da madeira. Viçosa: Sociedade de Investigações Florestais; 1984. (Boletim Técnico; 1).

Yamaji FM, Vendrasco L, Chrisostomo W, Flores WP. Análise do comportamento higroscópico de briquetes. Revista Energia na Agricultura 2013; 28(1): 11-15. 10.17224/ EnergAgric.2013v28n1p11-15 